\title{
Blood Group Distribution in Switzerland - a Historical Comparison
}

\author{
Thomas Volken $^{a}$ Rebecca J. Crawford ${ }^{\mathrm{a}, \mathrm{b}}$ Soraya Amar ${ }^{\mathrm{c}}$ Edgar Mosimann ${ }^{\mathrm{d}}$ \\ Anita Tschaggelar ${ }^{\mathrm{C}}$ Behrouz Mansouri Taleghani $^{\mathrm{A}}$ \\ a School of Health Professions, Zurich University of Applied Sciences, Winterthur, Switzerland; \\ ${ }^{b}$ Faculty of Health Professions, Curtin University, Perth, Australia; \\ c Swiss Transfusion SRC, Swiss Red Cross, Bern, Switzerland; \\ ${ }^{\mathrm{d}}$ Militärärztlicher Dienst, Swiss Army, Bern, Switzerland; \\ e Department of Hematology and Central Hematology Laboratory, Inselspital, Bern University Hospital and University of Bern, \\ Bern, Switzerland
}

\section{Keywords}

Blood group - Ethnic minority - Rare blood types . Switzerland

\section{Summary}

Background: Ethnicities differ in prevalence of blood groups and antigens. Substantial donor-recipient mismatch within mixed-ethnic societies may render certain recipients at higher risk for alloimmunization. Data regarding antigen distribution within Switzerland by ethnicity is limited. We examined immigration patterns against the distribution of $A B O$ blood groups using large cross-sectional Swiss samples spanning 70 years. Methods: Historical ABO blood group distribution data (1940-1945) from Swiss army personnel $(n=275,664)$ were sourced from the literature. Recent blood group phenotypes of 122,925 individuals who presented themselves at army recruitment centers (2004-2015) were obtained, alongside a validation sample of 175,202 patients from a university hospital. Two-sample tests with z-statistics assessing blood groups between samples were used. Results: The respective proportions of $A(47.2 \%$ and $45.2 \%), B(8.4 \%$ and $9.8 \%)$, and $A B$ (3.0 and 4.1) in the historical and recent army samples were significantly different $(p<0.001)$, while group $O$ was not. Conclusion: ABO blood groups in Switzerland have remained stable despite substantial immigration with a changing foreign-national profile. Further research is needed to improve the understanding of antigen differences in newly introduced ethnic groups. Blood product requirements and public health initiatives aimed at recruiting blood donors would benefit from this information.

(c) 2017 S. Karger GmbH, Freiburg

\section{Introduction}

The impact of migration and ethnic minority groups on blood supply and blood demand has been widely studied. It is well established that ethnic groups can differ in their prevalence of blood groups [1-9] and blood group antigens [10-15]. Compared to European frequencies, substantial antigen differences were found between individuals of African, Asian, Native American, and Polynesian origin $[12,13,15,16]$. This presents a problem for mixed-ethnic societies wherein a substantial donor-recipient mismatch may render some ethnic-group recipients at higher risk for alloimmunization [11, 17-19]. Moreover, certain ethnicities may have a higher proportion of diseases requiring transfusions, like sickle cell anemia. Several studies report that individuals from African, Latin American, and Mediterranean origin are at higher risk for sickle cell disease [19-21], with these patients having a known predisposition to alloimmunization [22]. As a further complication toward meeting health services demand, studies indicate that immigrants and ethnic minorities are less involved in blood donation [21, 2330]. This may cause severe problems in supplying adequate blood products to ethnic minorities when the latter differ substantially in their antigen expression from the majority population [31].

Not surprisingly, the European Blood Alliance initiated the Missing Minorities (MIMI) project in 2012, which aimed to make an inventory of the current state of minority participation and recruitment efforts for blood donors according to each of the 34 participating countries $[31,32]$. Unfortunately, Switzerland was not part of this project for several reasons. Firstly, most blood establishments in Switzerland record neither the ethnic background nor the country of birth of their donors. Secondly, antigen genotype analyses are not routinely performed predominantly due to the high costs involved. Thirdly, and probably most influentially, the

\section{KARGER}

(c) 2017 S. Karger GmbH, Freiburg

Fax +497614520714 
Fig. 1. Foreign and Swiss resident population 1900-2015.

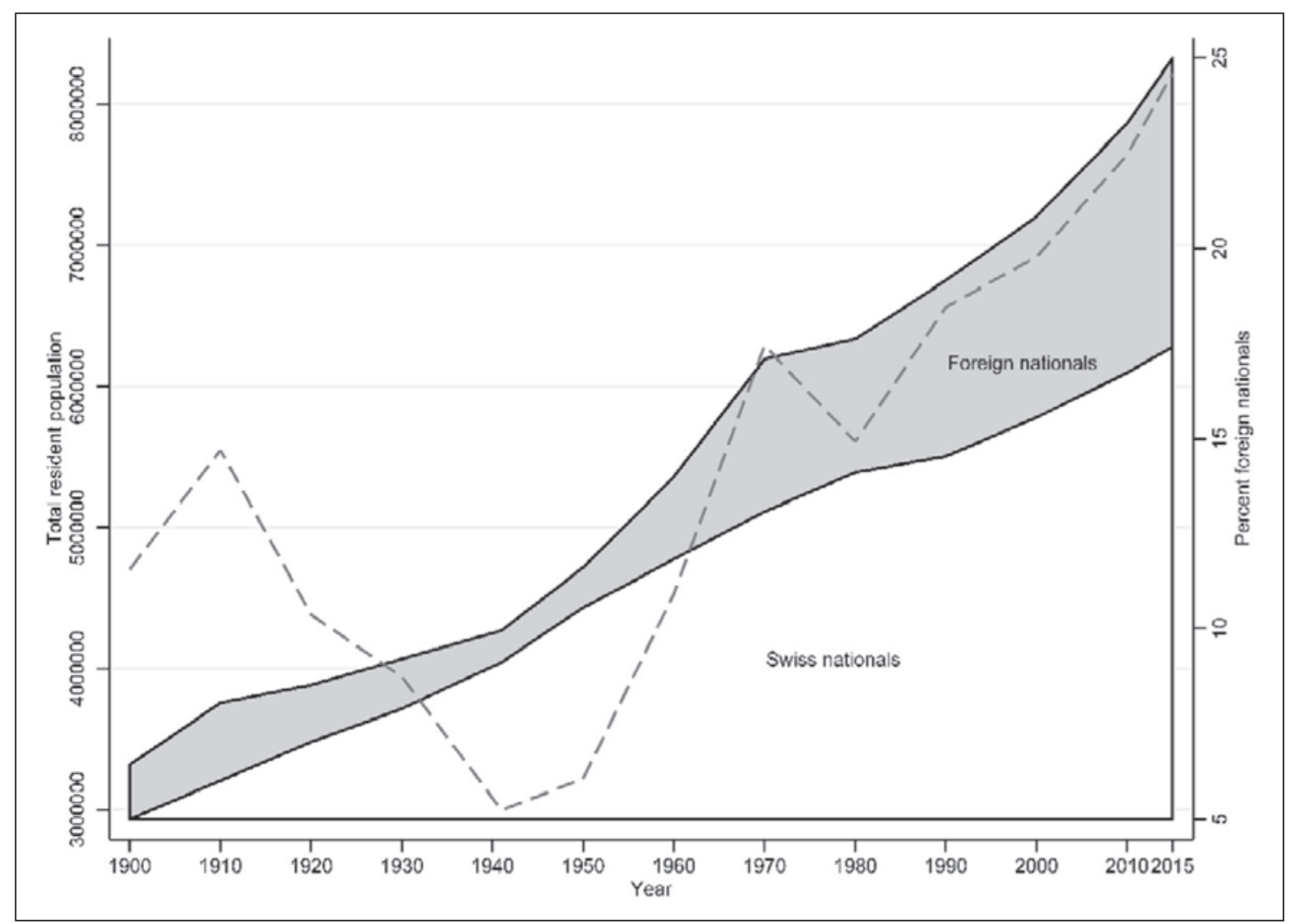

general awareness of immigration-related blood supply issues outlined above has only developed and gained momentum somewhat recently. Given Switzerland has a long immigration history, this is quite surprising.

With exception of the period between the two World Wars (1914-1945), in the past 115 years, Switzerland has had a considerable and escalating population of foreign nationals (fig. 1). In 2015, foreign nationals amounted to 2,048,667 individuals or $24.6 \%$ of the total permanent resident population.

Despite this impressive history of Swiss immigration, no comprehensive epidemiological data on the distribution of antigens in different ethnic groups exist. We therefore aimed to explore the impact of immigration and changed immigration patterns over time on the distribution of $\mathrm{ABO}$ blood groups using large crosssectional samples derived in Switzerland spanning a 70-year period.

\section{Material and Methods}

\section{Study Design}

The study is a secondary analysis of register-based, cross-sectional data on ABO blood groups collected from two time-points: historical (1940-1945) and recent (2004-2008 and 2011-2015).

\section{Study Population and Data}

Aggregated historical data on ABO blood groups were obtained from Rosin's report on ABO blood groups in Switzerland [1]. ABO blood group phenotypes of 275,664 Swiss army personnel and air-raid wardens were collected between 1940 and 1945 .
Recent data on $\mathrm{ABO}$ and $\mathrm{RhD}$ blood groups were obtained from the Swiss Army and the Inselspital (Bern University Hospital). The Inselspital, one of five university hospitals in Switzerland, is one of the largest hospitals with more than 8,000 employees and more than 40,000 treated patients per year. Swiss Army data comprised $\mathrm{ABO}$ and $\mathrm{RhD}$ blood group phenotypes of 122,925 individuals who presented themselves at one of the six local recruitment centers between 2004 and 2008 or 2014 and 2015. Swiss Army enrolment is mandatory for all male Swiss nationals, while female Swiss nationals can volunteer. Initial recruitment and participation is usually undertaken at or near age 19 and includes a baseline medical examination where blood samples are drawn. Given military or civil service is compulsory, the blood samples obtained from the army are considered a representative sample of male Swiss nationals. We therefore validated the distribution of $\mathrm{ABO}$ blood groups derived from recent army data with corresponding data from a large sample of patients $(n=175,202)$ who were treated in the Inselspital between 2011 and 2015. Unlike individuals in military recruitment centers, patients in hospitals are not exclusively Swiss nationals. Rather, patients can be considered representative of the distribution of foreign and Swiss nationals, based on the assumption that diseases randomly but equally affect foreigners and Swiss. Consequently, the $\mathrm{ABO}$ and $\mathrm{RhD}$ distribution based on recent Swiss army data should be considered representative if it coincides with the respective distribution in patients. However, Switzerland is comprised of seven major geographic regions (NUTS, Nomenclature des unités territoriales statistiques), and three major languages (German, French, and Italian). Substantial regional differences exist with respect to historical and recent immigration patterns, the number of foreign nationals, and the national origin of immigrants. Therefore, we expected differences in the distribution of blood groups within Switzerland. Consequently, we restricted the recent army sample to those individuals whose current registered place of residence was in a single major region, Espace Mittelland, as the Inselspital. Espace Mittelland encompasses the cantons of Bern, Fribourg, Jura, Neuchâtel, and Solothurn. While patients may have originated from different regions, we are confident that the vast majority resided within this regional perimeter. ABO blood groups derived from the regionally restricted army sample $(n=35,107)$ were then compared with those of patients. 
Table 1. Distribution of ABO blood groups 1940-1945 and 2004-2015

\begin{tabular}{|c|c|c|c|c|c|c|}
\hline \multirow[t]{2}{*}{$\mathrm{ABO}$ groups } & \multicolumn{2}{|c|}{$1940-1945$} & \multicolumn{2}{|c|}{ 2004-2015 } & \multirow[t]{2}{*}{$\% \mathrm{RhD}+$} & \multirow[t]{2}{*}{$\% \mathrm{RhD}-$} \\
\hline & $\mathrm{N}$ & $\%$ & $\mathrm{~N}$ & $\%$ & & \\
\hline A & 130,201 & 47.2 & 55,514 & $45.2 * *$ & 38.3 & 6.9 \\
\hline B & 23,263 & 8.4 & 12,068 & $9.8 * *$ & 8.4 & 1.4 \\
\hline $\mathrm{AB}$ & 8,327 & 3.0 & 5,038 & $4.1^{* *}$ & 3.5 & 0.6 \\
\hline $\mathrm{O}$ & 113,873 & 41.3 & 50,305 & 40.9 & 34.8 & 6.1 \\
\hline Total & 275,664 & 100.0 & 122,925 & 100.0 & 85.0 & 15.0 \\
\hline
\end{tabular}

Table 2. Distribution of $\mathrm{ABO}$ and $\mathrm{RhD}$ blood groups in the restrictive army sample and in the Inselspital sample

\begin{tabular}{|c|c|c|c|c|c|c|c|c|}
\hline \multirow[t]{2}{*}{$\mathrm{ABO}$ groups } & \multicolumn{4}{|c|}{ Swiss army (2004-2015) } & \multicolumn{4}{|c|}{ Inselspital (2011-2015) } \\
\hline & $\mathrm{N}$ & $\%$ & $\% \mathrm{RhD}+$ & $\% \mathrm{RhD}-$ & $\mathrm{N}$ & $\%$ & $\% \mathrm{RhD}+$ & $\% \mathrm{RhD}-$ \\
\hline A & 16,584 & 47.2 & 39.9 & 7.3 & 80,941 & $46.2^{*}$ & $38.7^{*}$ & 7.5 \\
\hline B & 3,190 & 9.1 & 7.7 & 1.4 & 18,170 & $10.4^{*}$ & $8.9^{*}$ & 1.5 \\
\hline $\mathrm{AB}$ & 1,452 & 4.1 & 3.5 & 0.6 & 7,161 & 4.1 & 3.5 & 0.6 \\
\hline $\mathrm{O}$ & 13,881 & 39.5 & 33.7 & 5.8 & 68,930 & 39.3 & 33.1 & 6.2 \\
\hline Total & 35,107 & 100.0 & 84.8 & 15.2 & 175,202 & 100.0 & $84.2^{\star}$ & 15.8 \\
\hline
\end{tabular}

Blood group distribution was calculated using all observations over all years in the respective samples; that is, we calculated unweighted proportions.

Yearly data on natural population change, permanent resident population, and migration by country of origin between 1900 and 2015 were obtained from the Swiss Federal Statistical Office.

\section{Statistical Analyses}

Two-sample tests of proportions with z-statistics to assess differences of corresponding ABO blood groups between samples were used. Stata 14.1 (StataCorp, College Station, TX, USA) was employed for all statistical analyses. Statistical significance was established at $\mathrm{p}<0.05$.

\section{Results}

Over a period of roughly 70 years, the $\mathrm{ABO}$ blood group distribution remained remarkably stable (table 1). The most prevalent blood group in both army samples (1940-1945 and 2004-2015) was $\mathrm{A}$, followed by $\mathrm{O}, \mathrm{B}$, and $\mathrm{AB}$. The respective proportions of $\mathrm{A}$ (47.2\% and $45.2 \%), \mathrm{B}(8.4 \%$ and $9.8 \%)$, and $\mathrm{AB}$ (3.0 and 4.1$)$ in the two samples were significantly different $(\mathrm{p}<0.001)$, while group $\mathrm{O}$ was not. However, the differences between 1940-1945 and 20042015 were marginal, wherein the 2004-2015 period showed $2 \%$ fewer individuals with blood type $\mathrm{A}$, whereas $1.4 \%$ and $1.1 \%$ more individuals had blood groups $\mathrm{B}$ and $\mathrm{AB}$, respectively. This result suggests that the blood group distribution has changed only marginally despite substantial immigration (fig. 1) in the past decades.

\section{Validation of Army-Based Blood Group Distribution}

The most prevalent $\mathrm{ABO}$ blood group of individuals in the regionally restricted army sample as well as in the patient sample was again $\mathrm{A}$, followed by $\mathrm{O}, \mathrm{B}$, and $\mathrm{AB}$ (table 2). Similarly, the most prevalent $\mathrm{ABO} / \mathrm{RhD}$ blood group in both samples was $\mathrm{A} \mathrm{RhD}+$, followed by $\mathrm{O} \mathrm{RhD}+, \mathrm{B} \mathrm{RhD}+, \mathrm{A} \mathrm{RhD}-, \mathrm{O} \mathrm{RhD}-, \mathrm{AB} \mathrm{RhD}+, \mathrm{B}$ RhD-, and AB RhD-. Patients had 1.2\% fewer A RhD+ (38.7\%) and $1.2 \%$ more $\mathrm{B} \mathrm{RhD}+(8.9 \%)$. Moreover, patients had $0.6 \%$ fewer $\mathrm{RhD}+(84.2 \%)$. Although statistically significant, the absolute differences were again marginal. Within individuals of the two samples, blood groups were not statistically different for blood groups O RhD+, O RhD-, A RhD-, B RhD-, AB RhD+, and AB RhD-. Overall, these results suggest that the $\mathrm{ABO} / \mathrm{RhD}$ distribution derived from data collected at army recruitment centers is a good approximation of the $\mathrm{ABO} / \mathrm{RhD}$ distribution of the total permanent resident population of Switzerland.

\section{Discussion}

Overall, we found that the frequency distribution of $\mathrm{ABO}$ blood groups in Switzerland changed only marginally over a period of roughly 70 years, despite a substantial and growing number of immigrants. In order to understand this persistence and hypothesize why general awareness for minority group blood products has developed only recently, we need to have a closer look at historical immigration patterns (fig. 2).

Up to 1960 , immigration comprised almost exclusively of individuals from the four neighboring countries: Austria, France, and particularly Germany and Italy. In 2015, they still accounted for $37.9 \%$ of all foreign nationals. These countries share a common European cultural heritage with Switzerland, and also share a similar distribution of $\mathrm{ABO}$ blood groups. With the exception of Italy where blood groups $\mathrm{O}(46 \%)$ and $\mathrm{A}(42 \%)$ were most prevalent, the 
Fig. 2. Major immigrant groups by nationality $1900-2015$

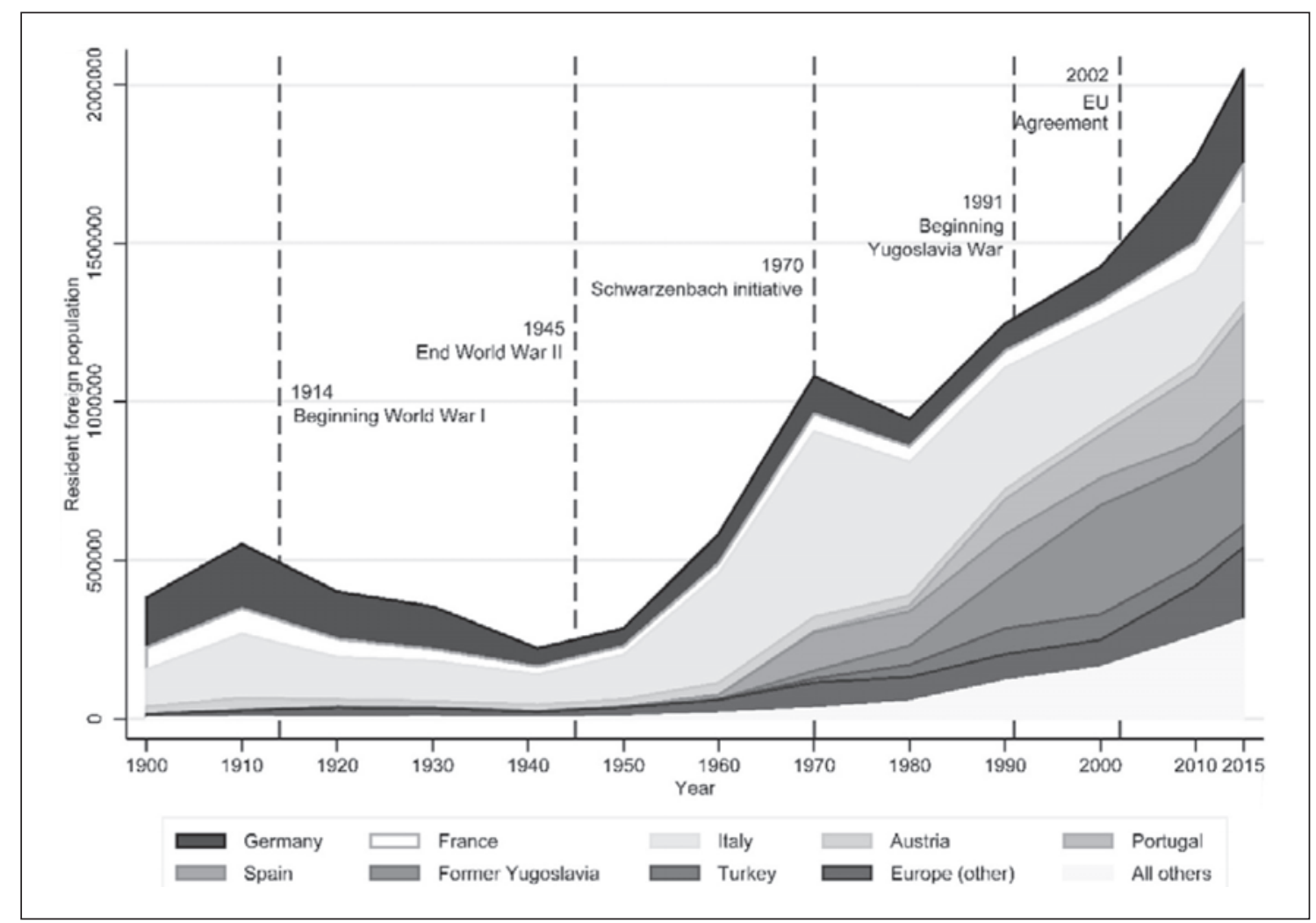

most common group in the remaining neighboring countries was A (range 43-45\%), followed by O (range 36-43\%), whereas B (9$14 \%)$ and $\mathrm{AB}(3-7 \%)$ were much less prevalent [33-36]. Especially between 1960 and 1980, immigration from Spain and Portugal became more prominent. Again, blood group distribution of these two countries was similar to Switzerland: A $(46-47 \%)>\mathrm{O}(38-$ $42 \%)>\mathrm{B}(8-10 \%)>\mathrm{AB}(3-5 \%)$. At the beginning of the 1990 s, immigration patterns started to change shortly after the onset of the wars in (former) Yugoslavia. In the aftermath of these wars, large numbers of individuals left their homelands, and many immigrated to Switzerland. Foreign nationals from successor states to Yugoslavia, i.e. Bosnia-Herzegovina, Croatia, Kosovo, Macedonia, Montenegro, Serbia, and Slovenia, amounted to 311,669 individuals permanently residing in Switzerland in 2015. Together with Italians $(311,742)$, they were the most prevalent immigrant group in that year. Studies on the distribution of blood groups in Serbia [7], Croatia [37], and Macedonia [38] found frequencies of A (39$43 \%)>\mathrm{O}(31-35 \%),>\mathrm{B}(16-18)>\mathrm{AB}(7-12 \%)$. Compared with the $\mathrm{ABO}$ blood group distribution in Switzerland, blood groups $\mathrm{B}$ and $A B$ were more prevalent, and may be associated with their increased prevalence shown in the 2004-2015 compared to the 19401945 army samples (table 1). It may also be associated with the higher prevalence of blood group B that we found in the sample of patients as compared to the regionally restricted 2004-2015 army sample (table 1). Among foreign nationals receiving Swiss naturalization, individuals from successor states to Yugoslavia were prominent in recent years and were the most prevalent group in 2016 [39]. Moreover, marriages between foreign and Swiss nationals are very common; in the last 15 years, these marriages accounted for well over 35\% of all marriages, and their proportion constantly increased from 1970 to 2001 [40]. Children from these families automatically receive Swiss citizenship. Consequently, nationalization and reproduction may be associated with increased prevalence of blood types $\mathrm{B}$ and $\mathrm{AB}$ in individuals who had to present at army recruitment centers. However, nationalization is not comprehensive, which may partially explain why we found a higher proportion of individuals with blood group B in the hospital sample as compared with the restrictive army sample.

From 1900 to 1990, immigration of non-European foreign nationals from geographic regions such as Africa, Asia, Latin America and Caribbean, North America, and Oceania was extremely rare (fig. 3). In 1991, the total resident foreign national population from these regions amounted to roughly 100,000 individuals or $8.4 \%$ of foreign nationals. However, this population more than tripled by 2015 and accounted for $15.3 \%$ of foreign nationals. Immigrants from Asia and Africa were more prevalent as compared to those from the Americas, the Caribbean, and Oceania. Moreover, they accounted for roughly three quarters of this population in 2015 (fig. 3).

Immigrants from Africa and Asia originated from many different countries. Since between- as well as within-country variation of ethnic groups is considerable, we cannot provide a comprehensive distribution of $\mathrm{ABO}$ blood groups for individuals by country or ethnic group. However, previous studies suggest that blood type $\mathrm{B}$ is much more prevalent in individuals of Asian and African origin than in those of European (Caucasian) origin [4, 41-45]. As with individuals from successor states to Yugoslavia, naturalization and reproduction may be associated with the higher frequency of blood 


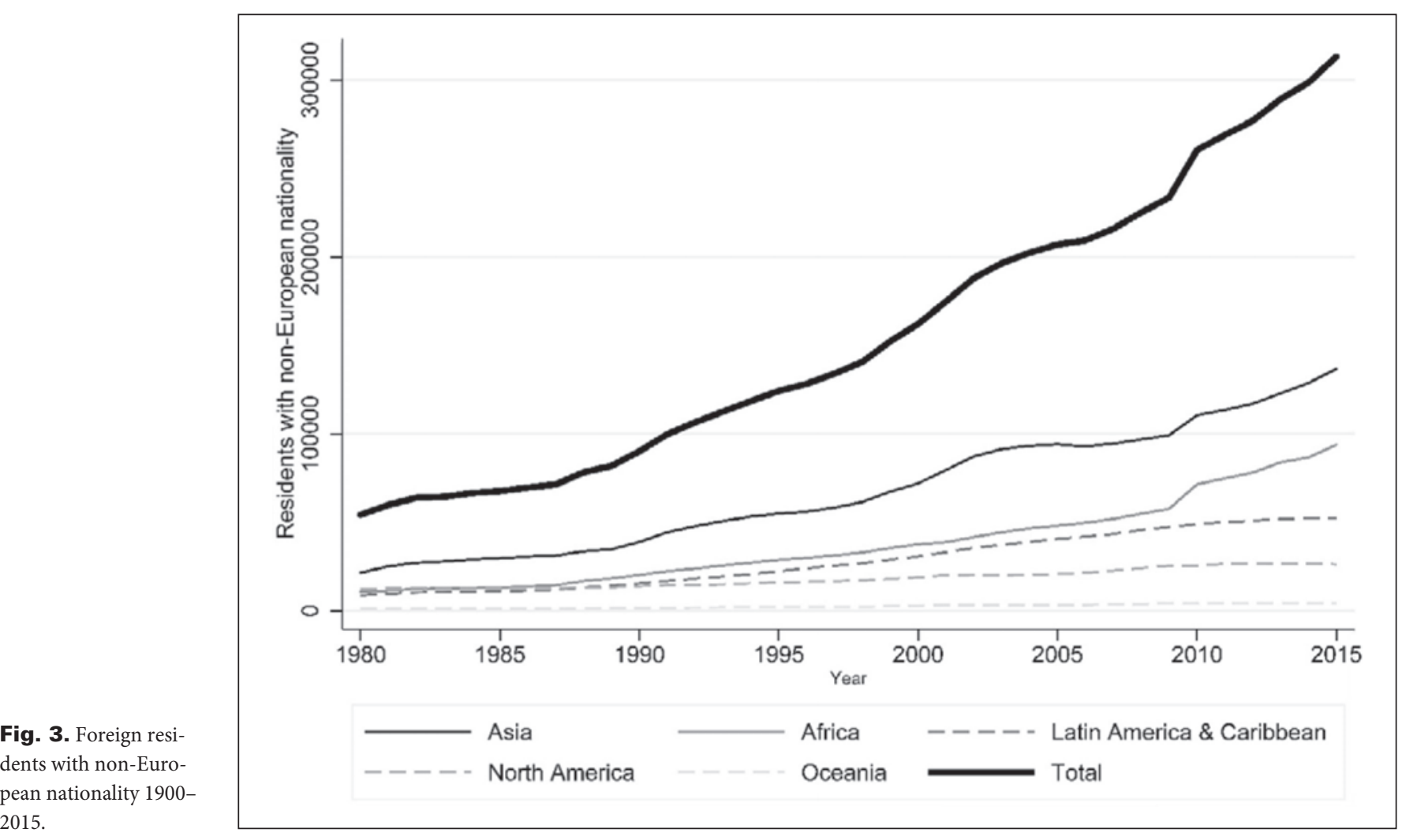

type B in the 2004-2015 army sample and the higher frequency in the sample of patients.

In summary, until recently, Switzerland has predominantly received immigration from (neighboring) European countries, which share an ethnicity and similar distributions of blood groups. In $2015,64.2 \%$ of foreign nationals were German, Italian, Portuguese, or French, or were nationals of one of the successor states to Yugoslavia. Only $15.3 \%$ were nationals from non-European countries, most importantly from Asia and Africa. However, individuals from Asia and Africa account only for $2.8 \%$ of the total current Swiss population. This immigration pattern with predominance of the Caucasian ethnicity, may explain why the distribution of blood groups has remained remarkably stable over 70 years.

While ethnic groups may not differ substantially in terms of regular $\mathrm{ABO}$ blood typing and hence blood group frequencies, they may differ in extended blood typing and the frequency of certain blood group antigens [10-15]. More specifically, studies describe substantial antigen differences in individuals of African and Asian origin as compared to individuals from Europe $[12,13,15,16]$.

The recent general awareness of, and public discussion for, the need of specific blood products for certain minority groups in Switzerland may be motivated by this small but growing population of Asian and African origin (2.8\%). Demographic forecasts suggest that the proportion of immigrants from Asia and Africa will continue to rise in the next decades [46]; this may lead to a more dramatic change in the national blood group profile than has been observed in the past. In anticipation of this probable consequence, immediate actions should be taken to ensure adequate supply of blood products for minority groups.

\section{Strengths and Limitations}

A major strength of the study is that a large number of individuals were available to estimate and validate the prevalence of $\mathrm{ABO}$ and $\mathrm{RhD}$ blood groups in Switzerland. However, the study should be interpreted in light of its limitations. Since we did not have information on any birth origin nationalities of naturalized Swiss, or information on parents' nationalities, our suggestion that naturalization and reproduction is associated with the increase in blood groups $\mathrm{B}$ and $\mathrm{AB}$ remains speculative. Moreover, information on the distribution of blood groups in foreign nationals was derived from the available literature where study years varied considerably. Consequently, $\mathrm{ABO}$ frequency in countries may have changed since the study took place. Furthermore, we assumed that immigrants to Switzerland did not substantially deviate in the distribution of their blood groups as compared to their country of origin's average population. However, this may not be the case if immigration is limited to certain ethnic groups.

Furthermore, statistical tests with unequal sample size may result in lower power for these tests. This may be specifically true for the comparison between the restrictive army sample $(\mathrm{n}=35,107)$ and the Inselspital sample $(n=175,202)$. However, in the restricted army sample, the precision of all $\mathrm{ABO}$ blood group population estimates were in the range between $\pm 1.0 \%$ and $\pm 1.1 \%$ and, due to higher sample size, even lower in the Inselspital sample. Moreover, the proportion of the least prevalent $\mathrm{ABO}$ blood groups, $\mathrm{AB} \mathrm{RhD}-$ and $\mathrm{B}$ $\mathrm{RhD}$-, were either identical or nearly identical between the two samples (table 2). Both, high precision for highly prevalent $\mathrm{ABO}$ blood groups and nearly identical proportions for the least prevalent $\mathrm{ABO}$ blood groups seem to support the credibility of our results. 
Finally, the methods for blood group typing have substantially increased in sensitivity in the last decades. Hence, misclassification of ABO blood group phenotypes that were collected between 1940 and 1945 is potentially much higher than misclassification in the more recent samples. While this may systematically bias our results, we are unfortunately not able to appropriately quantify and correct for the expected bias.

\section{Conclusion}

The distribution of ABO blood groups in Switzerland has remained stable between 1940 and 2015, despite substantial immi- gration with a temporally changing foreign national profile. Further research is needed to gain insight into the distribution of antigen differences between ethnic groups in Switzerland in order to guide the supply of blood products and to direct public health initiatives aimed at recruiting blood donors from less represented blood and minority groups.

\section{Disclosure Statement}

The authors declare no conflict of interests.

\section{References}

1 Rosin S: Die Verteilung der ABO-Blutgruppen in der Schweiz. Zürich, Archiv Klaus-Stiftung für Vererbungsforschung, 1956.

2 Lialiaris T, Digkas E, Kareli D, Pouliliou S, Asimakopoulos B, Pagonopoulou O, Simopoulou M: Distribution of $\mathrm{ABO}$ and $\mathrm{Rh}$ blood groups in Greece: an update. Int J Immunogenet 2011;38:1-5.

3 Maeda K, Nakamura S, Murakami C, Irie W, Watanabe T, Sasaki C, Nakamaru N, Furukawa M, Kurihara $\mathrm{K}$ : ABO genotyping by Taqman assay and allele frequencies in a Japanese population. Leg Med (Tokyo) 2013;15:57-60.

4 Ndoula ST, Noubiap JJ, Nansseu JR, Wonkam A: Phenotypic and allelic distribution of the $\mathrm{ABO}$ and rhesus (D) blood groups in the Cameroonian population. Int J Immunogenet 2014;41:206-210.

5 Ohashi J, Naka I, Kimura R, Tokunaga K, Yamauchi T, Natsuhara K, Furusawa T, Yamamoto R, Nakazawa M, Ishida T, Ohtsuka R: Polymorphisms in the ABO blood group gene in three populations in the New Georgia Group of the Solomon Islands. J Hum Genet 2006;51:407-411.

6 Said N, Ben Ahmed F, Doghri A, Ghazouani E, Layouni S, Gritli N, Nsiri B: The ABO system polymorphism in Tunisian blood donors (in French). Transfus Clin Biol 2003;10:331-334.

7 Vojvodic S: Distribution of the ABO, Rh, MNSS, Kell and Duffy blood group antigens in the population of Vojvodina (in Czechian). Med Pregl 2003;56:173-177.

8 Yan L, Zhu F, Fu Q, He J: abo, Rh, MNS, Duffy, Kidd Yt, Scianna, and Colton blood group systems in indigenous Chinese. Immunohematology 2005;21:10-14.

9 Howes RE, Patil AP, Piel FB, Nyangiri OA, Kabaria CW, Gething PW, Zimmerman PA, Barnadas C, Beall CM, Gebremedhin A, Menard D, Williams TN, Weatherall DJ, Hay SI: The global distribution of the DUFFY blood group. Nat Commun 2011;2:266.

10 Beattie KM, Cisco SL, Winkler MM, Shafer AW: The immediate and long-term benefits of a broad-based rare donor program. Immunohematology 1986;2:69-72.

11 Chou ST, Jackson T, Vege S, Smith-Whitley K, Friedman DF, Westhoff CM: High prevalence of red blood cell alloimmunization in sickle cell disease despite transfusion from Rh-matched minority donors. Blood 2013;122:1062-1071.

12 Delaney M, Harris S, Haile A, Johnsen J, Teramura G Nelson K: Red blood cell antigen genotype analysis for 9087 Asian, Asian American, and Native American blood donors. Transfusion 2015;55:2369-2375.

13 Karafin MS, Field JJ, Gottschall JL, Denomme GA Barriers to using molecularly typed minority red blood cell donors in support of chronically transfused adult patients with sickle cell disease. Transfusion 2015;55 1399-1406.
14 Vichinsky EP, Earles A, Johnson RA, Hoag MS, Williams A, Lubin B: Alloimmunization in sickle cell anemia and transfusion of racially unmatched blood. N Engl J Med 1990;322:1617-1621.

15 Noizat-Pirenne F: Immunohematologic characteristics in the Afro-Caribbean population. Consequences for transfusion safety (in French). Transfus Clin Biol 2003; 10:185-191.

16 Noizat-Pirenne F, Lee K, Pennec PY, Simon P, Kazup P, Bachir D, Rouzaud AM, Roussel M, Juszczak G, Menanteau C, Rouger P, Kotb R, Cartron JP, AnsartPirenne H: Rare RhCE phenotypes in black individuals of Afro-Caribbean origin: identification and transfusion safety. Blood 2002;100:4223-4231.

17 Badjie KS, Tauscher CD, van Buskirk CM, Wong C, Jenkins SM, Smith CY, Stubbs JR: Red blood cell phenotype matching for various ethnic groups. Immunohematology 2011;27:12-19.

18 Castro O, Sandler SG, Houston-Yu P, Rana S: Predicting the effect of transfusing only phenotype-matched RBCs to patients with sickle cell disease: theoretical and practical implications. Transfusion 2002;42:684-690.

19 Frye V, Caltabiano M, Kessler DA, Schaffler H, Reboza M, Hillyer CD, Shaz BH: Evaluating a program to increase blood donation among racial and ethnic minority communities in New York City. Transfusion 2014; 54:3061-3067.

20 Modell B, Darlison M: Global epidemiology of haemoglobin disorders and derived service indicators. Bull World Health Organ 2008;86:480-487.

21 Shaz BH, Demmons DG, Crittenden CP, Carnevale CV, Lee M, Burnett M, Easley K, Hillyer CD: Motivators and barriers to blood donation in African American college students. Transfus Apher Sci 2009;41:191-197.

22 Anstee DJ: Red cell genotyping and the future of pretransfusion testing. Blood 2009;114:248-256.

23 Shaz BH, Demmons DG, Hillyer KL, Jones RE, Hillyer $\mathrm{CD}$ : Racial differences in motivators and barriers to blood donation among blood donors. Arch Pathol Lab Med 2009;133:1444-1447.

24 Shaz BH, Hillyer CD: Minority donation in the United States: challenges and needs. Curr Opin Hematol 2010; 17:544-549.

25 Shaz BH, James AB, Hillyer KL, Schreiber GB, Hillyer $\mathrm{CD}$ : Demographic patterns of blood donors and donations in a large metropolitan area. J Natl Med Assoc 2011;103:351-357.

26 Lattimore S, Wickenden C, Brailsford SR: Blood donors in England and North Wales: demography and patterns of donation. Transfusion 2015;55:91-99.

27 James AB, Demmons DG, Schreiber GB, Hillyer CD, Shaz BH: Contribution of attitudinal factors to blood donation in African American church attendees. Transfusion 2011;51:158-165.
28 James AB, Hillyer CD, Shaz BH: Demographic differences in estimated blood donor eligibility prevalence in the United States. Transfusion 2012;52:1050-1061.

29 James AB, Schreiber GB, Hillyer CD, Shaz BH: Blood donations motivators and barriers: a descriptive study of African American and White voters. Transfus Apher Sci 2013;48:87-93.

30 Veldhuizen IJ, Doggen CJ, Atsma F, De Kort WL: Donor profiles: demographic factors and their influence on the donor career. Vox Sang 2009;97:129-138.

31 Wagenmans ET, van Dongen A, de Vogel K, de Kort WLAM: Minorities and the blood supply: the missing minorities or MIMI-project. Vox Sang 2013;105:95-95.

32 van Dongen A, Mews M, de Kort WLAM, Wagenmans E: Missing minorities - a survey based description of the current state of minority bood donor recruitment across 23 countries. Diversity and Equality in Health Care 2016;13:138-145.

33 DRK-Blutspendedienst: Blutgruppen \& Verteilung in der Bevölkerung. www.drk-blutspende.de/spenderservices/ blutgruppen-und-verteilung-in-der-bevoelkerung.php (last accessed July 5, 2017).

34 Österreichisches Rotes Kreuz: Blutgruppen und $\mathrm{Rh}$ in Österreich www.roteskreuz.at/blutspende/blut-imdetail/wissenswertes-ueber-blut/blutgruppen/ (last accessed July 5 , 2017).

35 Institut national de la transfusion sanguine: Groupes sanguins www.ints.fr/sangtransfgrsanguin.asp $x$ (last accessed July 5, 2017).

36 San Marco Centro Donazione Sangue: Gruppi sanguigni: Diffusione nel mondo www.donatori-sanmarco.it/ gruppi-sanguigni-diffusione-nel-mondo/ (last accessed July 5, 2017).

37 Karabuva S, Carevic V, Radic M, Fabijanic D: The association of $\mathrm{ABO}$ blood groups with extent of coronary atherosclerosis in Croatian patients suffering from chronic coronary artery disease. Biochem Med ( $\mathrm{Za}-$ greb) 2013;23:351-359.

38 Kostovski M, Makarovska-Bojadzieva T, Blgoevska M Blood group distribution of $\mathrm{ABO}$ antigens and rhesus blood groups system in the Macedonian and Albanian population in the Republic of Macedonia. Int J Biol Med Res 2014;5:3988-3990.

39 State Secretariat for Migration: Ausländerstatistik www.sem.admin.ch/sem/de/home/publiservice/statistik/ auslaenderstatistik.html (last accessedJuly 5, 2017)

40 Bundesamt für Statistik: Statistik der Natürlichen Bevölkerungsbewegung (BEVNAT). Neuchâtel, Bundesamt für Statistik; Sektion Demografie und Migration, 1970-2016.

41 Nogareda Barbudo A: Grupos sanguineos en la población activa española. Anales de Medicina y Cirugia 1964;44:115-123. 
42 Hameed A, Hussain W, Janbaz A, Fazli-Rabbi, Quereshi JA: Prevalence of phenotypes and genes of $\mathrm{ABO}$ and rhesus $(\mathrm{Rh})$ blood groups in Faisalabad, $\mathrm{Pa}$ kistan. Pakistan J Biol Sci 2002;5:722-724.

43 Tesfaye K, Petros Y, Andargie M: Frequency distribution of $\mathrm{ABO}$ and $\mathrm{Rh}$ (D) blood group alleles in Silte zone, Ethiopia. Egypt J Med Hum Genet 2015;16:71-76.
44 Agrawal A, Tiwari AK, Mehta N, Bhattacharya P, Wankhede R, Tulsiani S, Kamath S: ABO and Rh (D) group distribution and gene frequency; the first multicentric study in India. Asian J Transfus Sci 2014;8: $121-125$.
45 Iwasaki M, Kobayashi K, Suzuki H, Anan K, Ohno S, Geng Z, Li G, Inoko $\mathrm{H}$ : Polymorphism of the ABO blood group genes in Han, Kazak and Uygur populations in the silk route of Northwestern China. Tissue Antigens 2000;56:136-142.

46 Bundesamt für Statistik: Szenarien zur Bevölkerungsentwicklung der Schweiz. 2015-2045. Neuchâtel, Eidgenössisches Departement des Innern. Bundesamt für Statistik, 2015 